\title{
Body Packer: An Experience in a Reference Hospital
}

Carlos A Lozano De Avila ${ }^{1}$, Giovanna M Rivas Zuñiga ${ }^{2}$, Katty C Square Nieves ${ }^{3}$, Nayib De J Zurita Medrano ${ }^{4}$, Jaime M Iglesias Medrano ${ }^{5}$

\begin{abstract}
The term body packer refers to the carrying of illegals in the body of a person with the aim of contraband. It is estimated that around $5 \%$ of the world's adult population used illicit drugs at least once in 2015. While most body packers are asymptomatic, a small percentage requires a surgical intervention due to complications such as intestinal obstruction. In the current report, we will present the case of a patient admitted with this complication to the emergency unit of a hospital in the city of Cartagena.
\end{abstract}

Keywords: Acute abdomen, Body packer, Laparotomy.

\section{Resumen}

El término Body Packer hace referencia al porte de sustancias ilegales en el cuerpo de una persona con el objetivo de contrabando. alrededor del $5 \%$ de la población adulta mundial, consumieron drogas por lo menos una vez en 2015, los pacientes en su mayoría son asintomático, sin embargo, existe un porcentaje de la población afectada que amerita intervención quirúrgica debido a la presencia de complicaciones como lo es la obstrucción intestinal. En el informe actual presentaremos el caso de un paciente que acude con manifestaciones severas a la unidad de urgencias de un hospital de la ciudad de Cartagena.

Palabras clave: Abdomen agudo, Body packer, Laparotomia.

Panamerican Journal of Trauma, Critical Care \& Emergency Surgery (2021): 10.5005/jp-journals-10030-1309

\section{BACKGROUND}

The term body packer (also known as "mule", "mail", or "culero") refers to a subject carrying foreign objects intra-abdominal, generally such as latex, rubber, or cellophane wrappers, containing cocaine, heroin, hashish, amphetamines, or other illegal drugs, for smuggling purposes. ${ }^{1}$ An estimated 250 million people, or about $5 \%$ of the world's adult population used drugs at least once in 2015. Even more disturbing is the fact that some 29.5 million of these users, or $0.6 \%$ of the world's adult population, suffer from drug use. In the short term, the influx of drug money can increase investment and increase countries' gross domestic product. But its effects can be negative in the long-term, particularly when the product in question covers a considerable percentage of the total economy of a community or country. ${ }^{2}$

During the last 30 years, Colombia has been linked and recognized in other nations for being a country of origin in the production and trafficking of narcotics, such as cocaine and marijuana; however, the authorities have done everything possible to control its production and distribution. ${ }^{3}$

Although most illicit substances are transported around the world by sea, road/train, or air transport in different forms of packaging, concealment within a person's body remains a frequent mode of transport in smaller quantities. This seems to be an increasingly worrisome topic, with many publications in the last decade, compared with the absence of publications before the 1970s. Concealment can be the result of oral ingestion of packages containing substances, the so-called "body packaging". ${ }^{4}$ It would be necessary to establish the difference with the body-stuffer that would be those subjects who are caught with an illicit substance and who try to hide it from the police members by ingesting it, in this case, the amount of substance ingested being much less. On the other hand, those subjects who hide the capsules with illicit drugs in the

\footnotetext{
${ }^{1-3}$ Department of Bolivar, Universidad Del Sinu Seccional Cartagena, Cartagena, Colombia

${ }^{4,5}$ Department of General Surgery, Universidad Del Sinu, Cartagena,
} Colombia

Corresponding Author: Carlos A Lozano De Avila, Department of Bolivar, Universidad Del Sinu Seccional Cartagena, Cartagena, Colombia, Phone: +913008050768, e-mail: clozanod10@icloud.com

How to cite this article: De Avila CAL, Zuñiga GMR, Nieves KCC, et al. Body Packer: An Experience in a Reference Hospital. Panam J Trauma Crit Care Emerg Surg 2021;10(1):43-45.

Source of support: Clinical history and clinical case

Conflict of interest: None

vagina or anus are called body-pusher. ${ }^{1}$ The psychotropic substance most frequently associated with BP is cocaine, a psychostimulant alkaloid (obtained from the Erythroxylon coca plant). Its half-life is 30-90 minutes, and it is metabolized by plasma and liver enzymes to water-soluble compounds that are excreted in the urine. ${ }^{5}$

\section{Materials and Methods}

The presentation of a clinical case is carried out in a reference hospital in the city of Cartagena and the subject is reviewed. In the current report, we detail the case of a middle-aged man who developed symptoms of drug toxicity. An abdominal CT scan confirmed the presence of capsules in the rectal ampulla but underestimated the burden and content of the ingestion, which was later confirmed by endoscopy and surgical recovery.

\section{Clinical Case Description}

A 52-year-old male patient from the city of Bogotá, resident in the city of Cartagena de Indias, with a history of behavioral disorders, 
who entered the NHBG emergency service with his wife with an altered state of consciousness, before presenting emetic episodes with subsequent self-medication with metoclopramide, a family member comments to find the patient lying on the floor with missing metoclopramide capsules. At hospital admission, the patient in poor general condition without neurological response with Glasgow 6/15, TA $90 / 60 \mathrm{~mm} \mathrm{Hg}, \mathrm{HR}$ : 90 , there is paleness of the mucous membranes, generalized redness, spasticity in upper and lower limbs, with subsequent episodes of agitation and movements generalized myoclonus, with absent pupillary reflex, miotic pupils, no response to painful stimuli, resistant abdomen, given these findings we proceed to management with biperiden due to initial suspicion of metoclopramide intoxication, antibiotic neuroprotection is started since neuroinfection is not ruled out, paraclinical general normal, negative urine toxicological profile, EKG with sinus tachycardia, t peaks on the anterolateral face, positive cardiac biomarkers, and echocardiogram with preserved ventricular function.

Imaging studies such as computerized axial tomography of the normal brain and simple abdominal tomography with incidental finding of gastric distention due to hyperdense material, identifying, in turn, two well-defined images in the rectal ampulla, compatible with probable capsules of content to be determined toward the rectal ampulla. The patient is transferred to the intensive care unit where treatment with benzodiazepines is started. The rectal examination performed, found two mobile stone masses in the ampulla. Their characteristics suggest a body packer. The patient underwent anoscopy with digital extraction of two capsules. One of the capsules was torn and probably caused the symptoms. The capsules are handed to authorities (chain of custody). Repeated rectal examination found no other mass in the ampulla. Laparoscopic examination ruled out perforation of the hollow viscera, and upper digestive tract endoscopy identified a foreign body of a tubular shape in the stomach. A polypectomy loop is introduced but could not extract the foreign body. Therefore, an urgent exploratory laparotomy is conducted where 10 foreign bodies were extracted, indicating a body packer (Figs 1 and 2). Later progress notes document clinical improvement in the postoperative period, surveillance in the intensive care

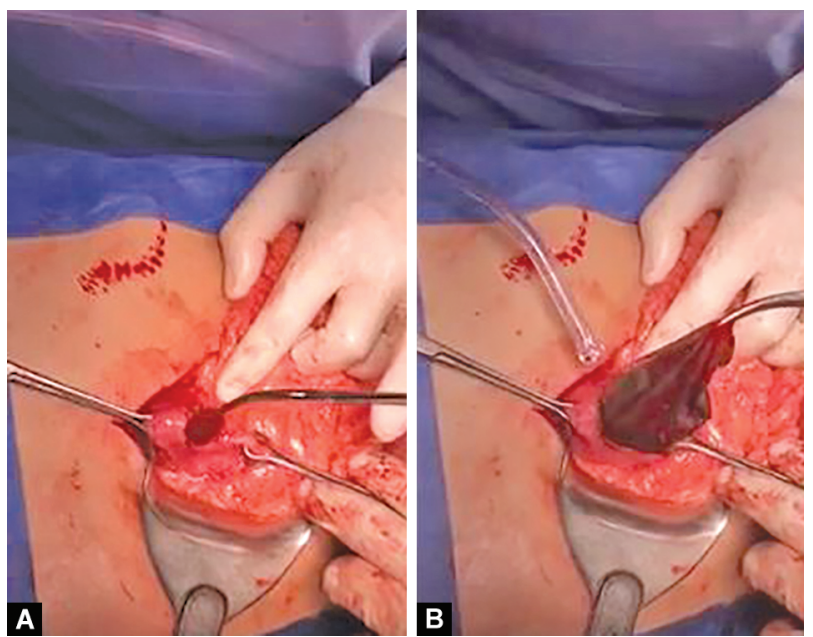

Figs $1 \mathrm{~A}$ and $\mathrm{B}$ : (A) Extraction of the foreign body via exploratory laparotomy, in a body packer; (B) Extraction of a pack via open laparotomy, in a body packer unit for 5 days, with subsequent hospital discharge on the tenth postoperative day. The case is presented to law enforcement for its respective diligence.

\section{Discussion}

The "BP syndrome" itself is defined as a picture of intestinal obstruction and/or intoxication secondary to the transport of drug packages in the digestive tract. It affects 1-9\% of all BP, with a mortality of $<1 \%{ }^{5}$ The possibility of complications will depend on the total amount and nature of the drug, integrity, strength, and location of the packages, and the time they stay in the digestive tract. $^{6}$ Systemic toxicity depends on the nature of the contraband. The most common toxic syndromes seen are opioid and sympathomimetic toxicity; others such as sedative-hypnotics, hallucinogens, and anticholinergics may also be seen. ${ }^{7}$ The diagnosis of this entity includes the realization of toxicological tests and the use of images, the positive detection of the toxicology of the urine does not indicate the rupture of the package because the leakage of the drug is a known phenomenon and some are active drug addicts. ${ }^{5}$ Most studies have reported that plain abdominal radiography has a sensitivity of $85-90 \%$ for detecting body packer, there have been studies that reported sensitivities as low as $47 \%$ and even one large recent prospective trial that reported a sensitivity of only $77 \% .{ }^{8}$ Although the abdominal X-ray is the most commonly used modality, it can be false-negative. ${ }^{9}$ Computerized axial tomography is superior in sensitivity, specificity, positive predictive value, and negative predictive value of plain abdominal film in evaluating body packing due to its improved contrast resolution and the absence of projections of overlapping structures in cross sections. Its sensitivity ranges from 95.6 to $100 \% .^{10}$

Treatment includes conservative attitudes, with high-resolution rates, and urgent surgical procedures (5\% of cases) in cases of intoxication, upper gastrointestinal bleeding, perforation of the hollow viscus, seizures, and/or high blood pressure that is resistant to medical treatment and intestinal obstruction, resistant to conservative treatment. ${ }^{11}$ Most packages are disposed of within 30 hours, although some body packers may have taken anticholinergic agents or opiates to delay transit time. ${ }^{12}$

Here are different extraction techniques considering the segment where the object is located. A retained rectal foreign body can be classified as high or low based on its location relative to the rectosigmoid junction. This is important in-patient management as there is evidence to suggest that objects located above the rectum at presentation are more likely to require surgical intervention, whereas foreign bodies that can be palpated on a digital rectal exam can be removed in the emergency department. ${ }^{13}$ The endoscopic removal technique

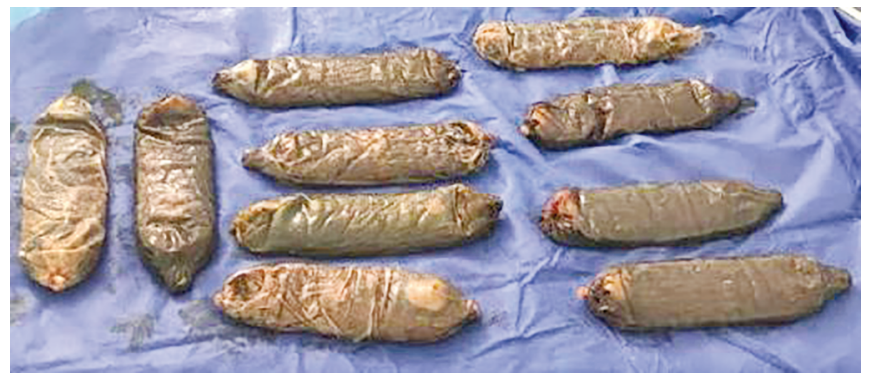

Fig. 2: Foreign bodies removed during a laparotomy 
involves the use of a flexible endoscope to extract objects that are more proximally located in the rectum or distal sigmoid colon. It provides a great visualization of the mucosa, and a polypectomy trap can be used to help remove the foreign body. Removal of a sharp object requires endoscopy and also removal of the sharp tip, at the time of extraction, to avoid injury. ${ }^{14}$

There are no universally accepted criteria on the indications for urgent surgery ( $<5 \%$ of BPs) and/or the type of surgical technique to be used. According to some authors, any of the following would be absolute indications for laparotomy: signs of adrenergic intoxication, upper gastrointestinal bleeding, perforation of the hollow viscus or peritonitis, seizures and/or hypertension that are resistant to medical treatment, and intestinal obstruction resistant to conservative management. ${ }^{5}$

The goal of surgery is a complete exploration and total intestinal clearance in the event of drug overdose and to relieve obstruction when the intestines become obstructed. There are different methods to perform surgeries such as gastrostomy, multiple enterotomies, single enterotomy, and pack removal per year after milking the packs distally. ${ }^{15}$ Laparotomy with colostomy and removal of the foreign body may be indicated. ${ }^{16}$

\section{Conclusion}

The body packer syndrome, as we have well-reviewed, is an entity that we must consider in patients with acute abdomen with little collaboration during the interrogation, in these cases, the conservative treatment is initially the conduct to be taken, not leaving aside the surgical intervention which may be indicated in some cases.

\section{References}

1. González García J, Querol Fernández J, Querol Gutierrez J. Abdomen agudo en el síndrome de body packer. Formación Médica continuada en Atención Primaria 2015;22(5):291-293. DOI: 10.1016/j.fmc.2014.07.003. Copyright @ 2015. Obtenido de https:// www-clinicalkey-es.ezproxy.javeriana.edu.co/\#!/content/journal/1s2.0-S1134207215001127.
2. Naciones Unidas. (2017). INFORME Mundial SOBRE LAS DROGAS 2017. Viena. Obtenido de http://www.unodc.org/wdr2017/field/ WDR_Booklet1_Exsum_Spanish.pdf.

3. Baquero-Villa MÁ. Investigación forense en un caso. Colombia Forense 2015. 95-99. DOI: 10.16925/cf.v3i1.1175.

4. Berger FH, Nieboer KH, Goh GS, et al. Body packing: a review of general background, clinical. La Radiolog Med 2015;120(1):118-132. DOI: 10.1007/s11547-014-0458-0.

5. Mandava N. Establishment of a definitive protocol for the diagnosis and management of body packers (drug mules). Emerg Med J 2011(2):98-101. DOI: 10.1136/emj.2008.059717.

6. Madrazo Z. Body packer: revisión y experiencia. Cirugia Española 2007;82(3):139-145. DOI: 10.1016/S0009-739X(07)71688-3.

7. Ray A. Body packer syndrome: a radiological denouement!. J Emerg Med 2018;55(2):260-263. DOI: 10.1016/j.jemermed.2018.04.005.

8. Esterson YB, Patel V, Nicastro J. Plain radiography may underestimate the burden of body packer ingestion: a case report. Clin Imag 2017;44: 57-60. DOI: 10.1016/j.clinimag.2017.04.006.

9. Poletti P-A. Screening of illegal intracorporeal containers ("body packing"): Is abdominal radiography sufficiently accurate? a comparative study with low-dose CT. Radiology 2012(3):772-779. DOI: 10.1148/radiol.12112767. Obtenido de https://www.scopus.com/ record/display.uri?eid=2-s2.0-84869987545\&origin=inward\&txGid= 140d1915ee9b4a56769b4845a4ba5966\#.

10. Sica G. Portada de seminarios en ultrasonido, CT y MRI. Seminars in Ultrasound, CT, and MRI 2015. 39-47. Obtenido de https:// www-clinicalkey-es.ezproxy.javeriana.edu.co/\#!/content/journal/1s2.0-S0887217114001036.

11. Palomeque JA, Footwear BS. Body-packer syndrome. Chilean Journal of Surgery. DOI: 10.4067/S0718-4026201400010000218.

12. Hantson P. Oesophageal and gastric obstruction in a cocaine body packer. J Foren Legal Med 2014;27:62-64. DOI: 10.1016/ j.jflm.2014.08.013.

13. Ayantunde AA. Approach to the diagnosis and management of retained rectal foreign bodies: clinical update. Techni Coloproctol 2013;17(1):13-20. DOI: 10.1007/s10151-012-0899-1. Obtenido de https://link-springer-com.ezproxy.javeriana.edu.co/article/.

14. Ologun $\mathrm{G}$. Successful retrieval of a retained rectal foreign body in the emergency department. Cureus 2018. DOI: 10.7759/cureus.2025.

15. Kulkarni V. Body packer syndrome. J Postgrad Med 2012(3):225-226. DOI: 10.4103/0022-3859.101646.

16. Goldberg J. Rectal foreign bodies. Surg Clin N Am 2010(1):173-184. DOI: 10.1016/j.suc.2009.10.004. 